\title{
Influencing Factors' Analysis about Sichuan Rural Surplus Labor Force Transferring
}

\author{
Yu-gang Suo \\ College of Economic Administration, Sichuan Agricultural University \\ Chengdu 611130, China \\ Tel: 86-155-2073-5389Ｅ-mail: blackhorse954@126.com \\ Xun-gang Zheng (Corresponding author) \\ College of Economic Administration, Sichuan Agricultural University \\ Chengdu 611130, China
}

Tel: 86-155-2073-5096 E-mail: zxg9@163.com

Wen-wen Shen

School of Business Administration, Zhongnan University of Economics and Law

Wu'han 430200, China

Tel: 86-158-2718-6423Ｅ-mail: blackhorse459@126.com

Received: October 12, $2010 \quad$ Accepted: October 29, 2010 doi:10.5539/jas.v3n2p206

\begin{abstract}
On the basis of analyzing the status quo of Sichuan rural surplus labor force transferring, and building a rural surplus labor force transferred model, this article gives quantizing analysis on the effect factor between 1990-2009 about Sichuan rural surplus labor force transferring, and getting the chief factor that affecting Sichuan labor force transferring is system binding and labor force transferred space. Finally this article made policy recommendations that promoting Sichuan rural labor force transferring
\end{abstract}

Keywords: Labor force transferring, Model, Integration between city and countryside

\section{Introduction}

The study about Sichuan rural surplus labor force transferring:

(1) Wu Yanxiang reviewed characteristics, full of challenges, opportunities and policy measures of Sichuan rural labor force transferring, whose articles are the important documents of earlier systemic studying Sichuan rural labor force transferring.

(2) Someone like Yu Zhenbin has investigated economic services, the income of farmers and consumption levels; and they have analyzed the problems and causes of Sichuan rural surplus labor force transferring. They also have discussed the future and responses of Sichuan rural labor force transferring. These articles are the important documents of investigating the rural surplus labor transferring.

(3) In recent years, the area of research documents is increasing and as well make many valuable achievements. However, generally speaking, previous studies more focus on effective transfer channels and countermeasures. They made a little study of the influence that Sichuan rural surplus labor force make to agricultural development. The latter study has significant meaning of rural surplus labor in the effective transfer and Sichuan agricultural development.

China is a large agricultural country. Problems about Agriculture, Rural areas and Peasantry is the key to build a moderately prosperous society in all respects and to construct socialistic harmonious society. The key of problems about Agriculture, Rural areas and Peasantry is Peasantry. The key of problems about Peasantry is how to expand their survival and development space, more rapidly to implement and then a well-off life's rich labor. 
The important way about how to solve the problems is rural surplus labor force transferring. Sichuan is china's large agricultural province, and the rural surplus labors bring many common features with the national background and also have its particularities. Effectively implementing the Sichuan rural surplus labor in reasonable transfer not only can improve peasantry's standard of living, promoting Sichuan's economic development but also can play an exemplary role about solving problems about Agriculture, Rural areas and Peasantry, promoting nice and fast development of china.

The rate of rural population of Sichuan is about $80 \%$. Since the reform and opening, Sichuan province's economy has been significant development. Handworks be replaced by mechanization greatly increase labor productivity. A large number of labor productivity is released in this process. But the level of industrialization and urbanization grew very slowly; development about the three large industries is just like very incongruous, whose render the increase of employment opportunities far behind the growth of rural surplus labor.

The uneven development in different areas proved to be a prominent issue in china's development process. Economic difference between regions is increasing in china's development process. This difference is also reflected in the different urbanization levels. The polarization between city and country bring a series of bad influence to china's economic development. The new territories calling ChengYu to be formed in June 2007 push the balanced urban and rural development process. How to effectively implement the balanced urban and rural rapid development are becoming the points in academia discussion. The key of solving the problem lies in that we should speed up china's urbanization development process. And the essence of urbanization is the process of rural labor force transferred to nonagricultural sectors, towards to the city. So the speed of the process of urbanization is decided by the speed of rural surplus labor force transferring. To solve the problem about how to speed up rural surplus labor force transferring must find out these factors which make most influence in labor force transferring.

Sichuan has thirty-eight million rural labors, which are of the china's rural labor total of 7. 5\%; the number of Sichuan rural labor is in the second place in china. Since the reform and opening, Sichuan rural surplus labor force has been increasing from 16.88 million in reform and opening time to 20 million now. This is not only the result of Sichuan population continue to rise and arable land is gradually diminishing in quantity, but also more the result of Chinese thirty years of reform and opening and developing. After china's economic reform starting from rural areas made a great motivation effect for agricultural production, Agricultural labor time save a lot and come into striking labor force surplus. The large number of Sichuan rural surplus labor is the most important restraining factor for agricultural development. And the reconfiguration of Sichuan rural surplus labor force namely labor force transferred from rural areas to urban non-agricultural areas have great significance. It is not only can alleviate the rural population's employment pressure but also is an important means to develop the rural economy. It is an important way to solve problems about Agriculture, Rural areas and Peasantry and the socialist new construction as well.

\section{The status quo and characteristics about rural surplus labor force transferring}

The total population of Sichuan province goes up from seventy-six million in 1990 to eighty-one million in 2009. Nonagricultural population also goes up from eleven million in1990 to twenty-one million in 2009. The non-agricultural population rate increase from fifteen percent in 1990 to twenty-six in 2009. As population increasing, the number of rural labors goes up from twenty-eight million to thirty-seven million. The number of people who engaged in agriculture, forestry, husbandry and fishery drop from twenty-six million to twenty-three million. In 2008, Sichuan province's transient population is about twenty-four million. Floating rate is twenty-three percent; meanwhile fifty-seven floating in Sichuan, the other floating out of Sichuan. In addition, about twelve million people work out of Sichuan all the years.

Sichuan rural labor force transferring can be roughly divided into start up, slowdown, to accelerate and stability four stages. The start up stage is between in 1983 and in 1988. In this period, as the great development of township enterprises, the rate of nonagricultural labors in all labors goes up twenty percent per year; the number of transferring is about six hundred thousand. The rate of nonagricultural labors in all labors goes up from four point eight percent in 1983 to thirteen point one percent in 1988. The slowdown stage is between in 1989 and in 1991. Owing to the readjustment, compressing infrastructure investment, government shut down or transfer part of low efficiency, higher energy use, seriously polluted township enterprises; that corresponding slowdown employment opportunities of rural labor force; that make the scale of transferring reduced and the speed slower. Nonagricultural labor force in rural areas only increase seven point nine hundred thousand in the three years. The number of transferring is two point six hundred thousand every year; it is only forty-four percent of less than upper stage. Meanwhile, as a large number of rural labors get into working age, the total population of rural 
labors net increase two million and eighty-seven hundred thousand; labors that rested in rural areas enormously increase. The accelerate stage is between in 1992 and in 1994. Since the readjustment stage, government preliminary has curbed economic expansion development; they also eliminate the national unacceptably bad shape of economic development. In particular, after Deng Xiaoping's speech in south areas, rural surplus labor force started transferring in a comprehensive scale. The total number of rural labor force increase from five million twenty-three hundred thousand in 1991 to nine million eighty-six hundred thousand in 1994. The increasing number is about four million fifty-four hundred thousand in three years; the average increasing number in one year is about one million fifty-one hundred thousand. The rate of nonagricultural labors in all labors goes up to twenty-five percent; the rate is eleven higher than rate in 1991. Since from 1995 is the stable time of transferring. The total number of rural labor force transferring has increased five hundred thousand. The number of transferring increased steadily, geographical distribution and trade continued expanding; the quality and efficiency were further improved.

In recent years, Sichuan province has achieved gratifying success in the rural surplus labor force transferring; the number of Sichuan agricultural labors is slowdown; population of transferring increase every year. Regional cooperation built up a new platform for transferring employment. Sichuan builds a series of labor brand; transferring employment achieved organization in order, etc.

\section{(1) The number of surplus labors is large; the number of transferring employment is rising}

The number of Sichuan rural labors is thirty-five million sixty-four hundred thousand in 2000, twenty-six working in agriculture, the others working in other industries. The number of rural labors is thirty-four million fifty-two hundred thousand in 2006, twenty-two million ninety-three working in agriculture, the others working in other industries. Population who work in agriculture descended three million thirty-seven; the descended rate is about twelve percent. The number of people who work in other industries climbed two million twenty-five hundred thousand; the climbed rate is about twenty-four percent.

\section{(2) Employment to form multiple patterns}

Rural labor force who engaged in other industries including mining, manufacturing, building, transportations, communications, wholesale and retail trade and catering are many.

\section{(3) Abandoning farness to beg nearness and to make ends meet}

Cost savings; fully using the existing social resources to get better jobs and high salary are the important considering factors for migrant workers choosing working areas. In recent years, in addition, as the factors like the only child, weakening of the spirit of hardships, missing the family relatively serious, many new breed of rural labors choose working areas that near their family or make money in local unit in order to improve the economy and look after their family.

\section{(4) Transition from a single to all family going out to work}

According to four thousand rural door spot check in Sichuan province in 2004, in outgoing migrant workers, the rate of their consort going out to work rise sixteen point six percent, the rate who work out with all their family reached twelve point eight percent.

\section{(5) Employment economy continued to develop in home and abroad}

According to the rural working group's introduction, the scope of Sichuan rural labor force transferring are one million twenty-seven hundred thousand more than last year; there are forty-two thousand workers transferred at home. Employment income that workers who working abroad exchanged only through the bank and post office attained eight point five billion, seventeen point nine percent more than last year.

\section{Analysis of influence factors and building model}

\subsection{Urbanized, industrialized standard "double low"}

With china's economic continuing development, the urbanization levels of Sichuan have a larger increase, but it still faced with a grim reality. The general characteristic is low urbanization level; the gap between city and country is increasing. In the present, if per capita GDP is about $\$ 800$, in accordance with the china's urbanization and economic development; the urbanization level should be reached $34 \%$, but in fact not up to $31 \%$, lower than the same period of $40.5 \%$, just corresponding average level of the early 1990s. And the gap between Sichuan and nation's urbanization level is constantly expanding as time goes on.

In accordance with the economic point of view, if a country's industry economics' contributions to GDP are more than agriculture's contributions, it comes into the industrial stage. At present, Sichuan's industry level is 
still very low; industrialization still is in the down level in china; industrialization degree is in accordance with the average level of china's 1980s; dropping ten years than the coastal developed areas. Overall appearance, Sichuan is in the prophase stage of industrialization; industry remains the focus of economic development.

\subsection{Three major industries of output and employment structures do not harmonize}

Sichuan is a big agricultural province; Agricultural output and the proportion of employment is higher than the average national level. Between in 1999 and in 2008, the proportion of agricultural output is nine point five percent higher than the national level; the average of employment proportion is ten point three percent higher than the national level as well.

\subsection{Output and employment proportion of Sichuan province's second and third industries are all lower than national level}

From the difference extent, between in 1999 and in 2008, the average rate of the second industry is seven point five percent lower than national average level; the average rate of the employment is six point two percent lower than national average level. In this decade, looking from the overall level, the gap between output and employment proportion of the second industry and national level is narrowed. But it is important to note that the gap between the output rate of second industry and national level showed us up and down fluctuation. This say that Sichuan province's output and employment rate of the second industry showed itself a inconsistent harmony. Except individual years $(1999,2004,2005)$, the gap between industry rate and national level is bigger than the gap between employment and national level. And in such a result of the main reason may be the second industrial estate investment deficiency, the internal structures without reason. The average rate of the third industrial output is one point nine percent lower than national level. In the ten years, the gap between both and national level basically dropped; the development trend is harmony. But saying the gap extent, the gap between employment rate of the third industry and national level is clearly higher than the proportion of the output gap. Comparing the average national level, relative to their output, the proportion of third industry employment is clearly low. The most likely reason about how to appear this situation is the internal structure, including industry structure unreasonable, which make for deficiency of employment capability.

\subsection{Building model of labor force transferring}

Rural surplus labor force transferring get many factors influence. Generally, the more rural surplus labors, the greater transfer capabilities, the wider transfer of space, the less barrier, the more conductive to the rural surplus labor to transfer. Therefore, the major factors of affecting rural surplus labor force transferring include: (1) the first industry labor productivity. The higher of the first industry labor productivity, the more of labor force who be released in rural areas. (2) Per capita net income of rural areas. The higher per capita net income of rural areas, the more it costs. It also makes against labor force transferring; it is the cost of labor force transferring. (3) The proportion of the second industry's output, the proportion of the third industry's output, the proportion of the third industry's employment, the proportion of non-national department employment; these four targets reflect the transferred space of rural force; the bigger of transferred space, the quicker of transferred speed. (4) System factors. China's duality economic system always has large influence in rural surplus labor force, this enact the proportion of market assigning resources as the factors of determining system factors.

Establish labor force transferred model as follows:

$$
\mathrm{LnY}=\mathrm{a}+\mathrm{bLnP}+\mathrm{cLnI}+\mathrm{dLnGDP} 2+\mathrm{eL} 2 \mathrm{nGDP} 3+\mathrm{fLnS}+\mathrm{gLnT}+\mathrm{hLnM}+\mathrm{e}
$$

Including: p: the first industry labor productivity; I: per capita net income of rural areas; GDP2: the proportion of the second industry output; GDP3: the proportion of the third industry output; S: the proportion of the second industry employment; T: the proportion of the second industry employment; M: the proportion of market assigning resources.

The gross number of rural labors $=$ (the number of urban employees-the number of urban workers)(the number of rural migrant workers who enter into cities)+(the number of country employees-the number of people who work in agriculture)(the number of nonagricultural labors in rural areas). Considering the date available, using the ratio of the first industry output and the first industry employment labors denote the first industry labor productivity; using the rate of market distributing GDP approximately show the proportion of market assigning resources; the calculating formula is: (GDP-local fiscal revenues)/GDP.

\subsection{Data analysis}

Using the software of Eviews make OLS analysis for computation model, getting the regression equation as follows: 
$\mathrm{LnY}=8.589+0.393 \mathrm{LnP}-0.363 \mathrm{LnI}+0.094 \mathrm{LnGDP} 2+0.676 \mathrm{LnGDP} 3+0.114 \mathrm{LnS}+0.488 \mathrm{LnT}+1.754 \mathrm{LnM}$

$$
\mathrm{R}^{2}=0.997 \quad \mathrm{~F}=612.367
$$

The regression equation is to better explain, and variables are in below 0.05 significant levels of passing the test.

Seeing from the results, the factors that affecting Sichuan rural labor force transferring make a taxis according to flexibility quotient's magnitude in turn: the proportion of market assigning resources $(\mathrm{M})$, the proportion of the third industry output (GDP3), the proportion of the third industry employment (T), the first industry labor productivity $(\mathrm{P})$, the proportion of the second industry employment $(\mathrm{S})$, the proportion of the second industry output (GDP2), per capita net income of rural areas (I),. As a representative system's deputation, the proportion of market assigning resources is 1.754 , which is the largest flexibility quotients; the four targets of reflecting labor force transferring space all are positive flexibility quotients, which show that system factors and labor force transferring space are important factors of affecting labor force transferring. The flexibility quotient of the first industrial labor productivity is also positive, this show that the releasing surplus labor force owing to the improving of the first industrial labor productivity have much influence of the rural surplus labor force as well. And the flexibility quotient of the first industrial labor productivity to labor force transferring is negative; just like the assumptions, but its flexibility quotient is not too much, so it has a limited influence to the surplus labor force transferring.

\section{Conclusions and improving suggestions}

\subsection{Conclusions}

According to the analysis above, we can draw three conclusions: (1) there are great deal of surplus rural labors in rural areas (2) system factors greatly restrain rural surplus labors transferring (3) at present, Sichuan province's city offers less employment opportunities, less transferring space, that constraints the labor force transferring speed. By inference, the fundamental reason of making Sichuan province's urbanization slowly is not inadequate supply of rural surplus labor force but system factors restraining and the second, third industries offering a serious shortage of employment posts in a dual economic structure. For further analysis, Sichuan province's proportion of the second industrial output is a little less than proportion of employment ratio; Sichuan province's industrialization is very low. Meanwhile the third industrial employment ratio is obviously lower than its output ratio; the proportion of the third industry output have big flexibility quotient; therefore, apart from the established system factors influence, Sichuan province's second industry has input deficiency; including industrial development deficiency, irrational ownership structure. The irrationality of the third industrial internal industry structure and possession structure result in that the employment offering of cities is far smaller than the demand for jobs of rural surplus labor force. It is the most important factor of influencing urbanization.

\subsection{Improving suggestions}

(1) Reform the household registration management system. Knowing from the model analysis, the smaller the system hindering the rural surplus labor force transferring, the higher of marketing degree; the rate of labor force transferring will be faster and faster; thus effectively promote the process of urbanization. And this kind of influence is very large. The government should be to minimize collateral damage begetting by system; actually, the city should gradually reform household management system; centralizing labors at a moderate speed; broadening big cities' conditions that rural labors formally become urban dweller from the countryside, using access conditions in place of birth control targets. Cities should actively carry out the population household management grads policy and the broaden access conditions. Small town should be completely be free and gradually establish systems that carve up town residence accounting in their living places; household registration system that carve up agricultural population and non-agricultural population as their careers; carrying out integrated management for urban and rural households. On this basic, the government can formulate preferential policies for encouraging professionals and investors as well.

(2) The second industrial reasonable development, increasing the input. Industrial development process itself creates many jobs, and it can contribute to the relevant industries in particular the development of third industry; meanwhile creating more jobs; and it also beneficial to the second industrial redundant labors transfer to the third industry.

Promoting non-national economic development. There are many small businesses in non-national economy; these are labor-intensive businesses; employment fashion varies; there are fewer restrictions for low level cultural and technology labors, and the threshold is lowness. Non-national economy can absorb much rural surplus labor force. Most of non-national businesses have low starting point, needing small investment, and can easily create many investment and consumption demand. The employment ratio's flexibility quotient of 
non-national part is very big; so as developing the second industry, the government should not blind to increase state-owned enterprises investment but be appropriate preferential policies to support and encourage non-national economy. Offering the good environment of equality for non-national economy; meanwhile, accelerate the pace of reform of state-owned enterprises.

(3) Developing the third industry and optimizing its industrial structure. Based on the third industrial output value, Sichuan government should actively encourage the development of the third industry to create more employment opportunities. More worth noting that the proportion of the third industrial employment has a high flexibility quotient in the model, and just in front of the analysis we know that the employment ratio of the third industry is obvious lower than its output ratio; so the key is not simply to increase the input of the third industry when we develop the third industry; We should optimize the internal structure of third industry, to accelerate the restructuring of ownership and increase the proportion of the non-national sectors.

\section{References}

DAI Bin, LIU Xiao-ying. (2005). The new thread of Sichuan regional economic development strategy. China's Economic Publishing House, 18-25.

LIU Jia-qiang, JIANG Hua, LUO Long. (2007). Sichuan rural labor force obtaining employment new characters and system analysis in the background of Production factors leavings. Sichuan Provincial Conditions. 14-15.

State statistic bureau of the people's republic of china. (2008). China statistical yearbook. Beijing: China's Statistical Publishing House, 18-20.

Statistics bureau of Sichuan province. (2008). Sichuan investigation team of the state statistics bureau. Statistical yearbook of Sichuan(2008). Beijing: China's Statistical Publishing House, 11-17.

TONG Xu-hong, MENG Xue-fei. (2005). Sichuan industrial structure restructuring and economic growth. China's Economic Publishing House, 35-38.

WANG Guo-sen. (2005). The countermeasure study to speed up urbanization of Sichuan province. China's Economic Publishing House, 16-18.

WU Yan-xiang. (2002). Sichuan rural labor force transferring, countermeasures research. Economic System Restructuring, 23-24.

XU Shi-qun. (2005). Pressing urbanization process and building the western strong provinces. China's Economic Publishing House, 32-35.

XU Zhen-bin, PENG Xiao-ju, FENG Jian-lin. (2008). Sichuan rural labor force transferring, farmer's income and consumption survey. Macroeconomics Study. 24-28.

Table 1. Summary Output Table

\begin{tabular}{|c|c|}
\hline \multicolumn{2}{|c|}{ Regression Statistic } \\
\hline Multiple R & 0.9986 \\
\hline R Square & 0.9972 \\
\hline Adjusted R Square & 0.9956 \\
\hline Standard Error & 0.0246 \\
\hline Observation Value & 20 \\
\hline
\end{tabular}

Table 2. Variance Analysis Table

\begin{tabular}{|c|c|c|c|c|c|}
\hline & df & SS & MS & F & Significance F \\
\hline Regression Analysis & 7 & 2.5853 & 0.3693 & 612.3662 & $2.3456-14$ \\
\hline Residuals & 12 & 0.0072 & 0.0006 & & \\
\hline Sum & 19 & 2.5925 & & & \\
\hline
\end{tabular}




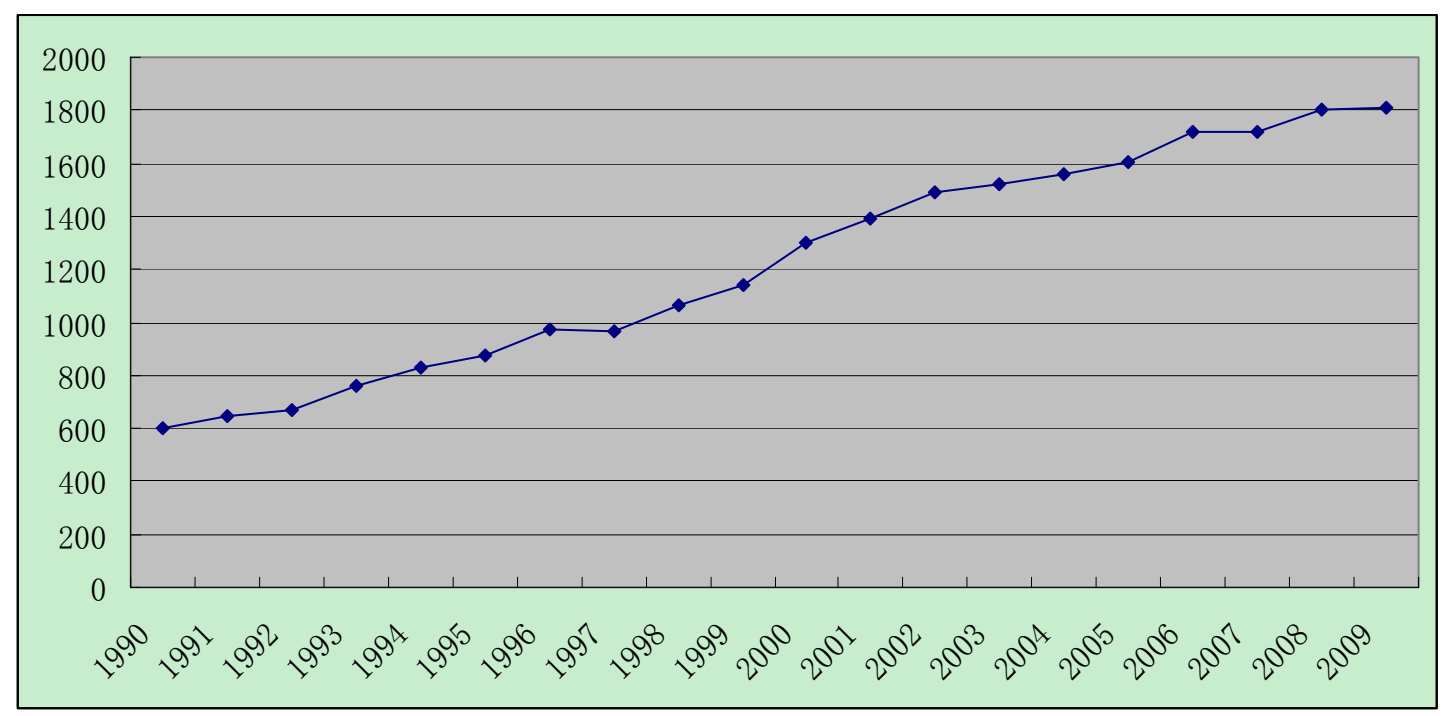

Figure. Trend figure of rural labor force transferring 